\title{
Gustave Bertrand: the Cooperation of British Intelligence with an Officer in Vichy France
}

Gustave Bertrand : la coopération du renseignement britannique avec un officier dans la France de Vichy

\section{Mona Parra}

\section{OpenEdition}

\section{Journals}

Electronic version

URL: https://journals.openedition.org/rfcb/8545

ISSN: 2429-4373

Publisher

CRECIB - Centre de recherche et d'études en civilisation britannique

Electronic reference

Mona Parra, "Gustave Bertrand: the Cooperation of British Intelligence with an Officer in Vichy France

", Revue Française de Civilisation Britannique [Online], XXVII-1 | 2022, Online since 04 January 2022 connection on 01 February 2022. URL: http://journals.openedition.org/rfcb/8545

This text was automatically generated on 1 February 2022.

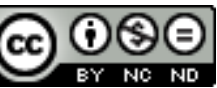

Revue française de civilisation britannique est mis à disposition selon les termes de la licence Creative Commons Attribution - Pas d'Utilisation Commerciale - Pas de Modification 4.0 International. 


\section{Gustave Bertrand: the Cooperation of British Intelligence with an Officer in Vichy France}

Gustave Bertrand : la coopération du renseignement britannique avec un officier dans la France de Vichy

Mona Parra

\section{Introduction}

1 The role British cryptanalysis played in the Allied victory of 1945 is now a well-known facet of World War Two, particularly the codebreaking of Enigma ciphers. However, the part France played in this achievement remains largely unknown.

2 France, and its cryptanalytic agency led by Gustave Bertrand, gave the British the intelligence and tools they needed to make their first breaks into Enigma. Very substantial exchanges took place between the two countries in this field just before the war and in the first months of the conflict. Surprisingly, the 1940 Armistice did not put an end to the French codebreaking activities or to their cooperation with the British. At that date, Bertrand faced a thorny dilemma common to many in France as to the best strategy to adopt in the new context. He took the difficult decision to remain in France, believing it was the best way for him to continue to fight against Germany. In Vichy France, he endeavoured to break German codes, working on a partly clandestine basis. On multiple occasions, he was ordered to put an end to his exchanges with the British. Nonetheless they went on until the Allied landings in North Africa in November 1942.

Though he represented a great asset for the British they feared he could also jeopardize all their efforts if the Germans discovered his activities and the extent of the successes they had achieved against Enigma. Intelligence derived from cryptanalysis is both invaluable and extremely fragile: had the Germans known Enigma was broken, they could easily have resorted to other codes or made this machine more difficult to break. 
International cooperation played a key role in the development of World War Two sigint (signals intelligence). Intelligence is part and parcel of the study of international relations, as Andrew and Noakes demonstrated in 1987 in Intelligence and International Relations, 1900-1945. ${ }^{1}$ Countless authors have focused on the Anglo-American intelligence relationship, since it yielded great results. ${ }^{2}$ Other intelligence alliances have received less attention. Eunan O'Halpin has tried to fill this gap through his work on UK-Irish sigint relations and on unequal cooperation; ${ }^{3}$ Bradley $\mathrm{F}$. Smith has examined the complex issue of how the Allies traded intelligence with Stalin. ${ }^{4}$ Information on the Franco-British relation can be found in books and articles dealing with the codebreaking of Ultra, in particular Enigma, The Battle for the Code by Hugh SebagMontefiore, ${ }^{5}$ or more recently X, Y \& Z. The Real Story of How Enigma was Broken, by Dermot Turing. ${ }^{6}$ His book offers unprecedented insight into the crucial relation between Polish codebreakers and Bertrand, and is based on remarkable Polish archives. This article seeks to analyse the stakes and nature of the exchanges between Bertrand and the British and to shed light on a lesser-studied aspect of Franco-British relations during the war. ${ }^{7}$

5 Internal notes which emanate from the secret services of the two countries as well as letters between Bertrand and the British have now been declassified by the intelligence agencies of the two countries. Most of these documents were not made public until 2004, and the French Service Historique de la Défense only released its "Fonds Bertrand" in 2015.8

6 This article will analyse a little-known yet crucial part France played in the Allied victory during the Second World War, far from the traditional images of the armed Resistance. Given the context, Bertrand's relations with the British codebreakers were often tense but remained crucial. Studying Bertrand's cooperation with the British also brings to light the complex balance of power between the two countries during the conflict.

\section{A fruitful intelligence alliance until May 1940}

7 The roots of the cooperation between the French and the British intelligence services can be traced back to World War One, which was a period of close collaboration between the two. ${ }^{9} \mathrm{~A}$ few exchanges also took place between the two wars, but this cooperation really took off in the second half of the nineteen-thirties. Numerous meetings between British and French intelligence officers took place during that period. Stewart Menzies, the deputy to the Chief of SIS (also known as MI6), met Lieutenant Colonel Rivet, the head of the French SR-SCR (Intelligence Division of the army), in October 1937. ${ }^{10}$ The Anschluss and the Munich Agreement led the British to realize the imminent threat posed by Germany. These events brought to light the urgent need for the two countries to overcome their reluctance and share their most precious secrets. ${ }^{11}$ A close cryptanalytic alliance really started at the very end of 1938 . The leading French figure of French cryptanalysis was Gustave Bertrand, born in 1896. He was described by Kim Philby, the British spy who defected to Moscow, as " $a$ fat unpleasant character, as silent as an oyster". ${ }^{12}$ The career of Bertrand, who joined the army as a private, is quite astonishing. Bertrand had enlisted as a volunteer in the infantry in August 1914. He was assigned to intelligence duties in 1919 and gradually rose through the ranks. In 1931, he received invaluable documents on the Enigma machine from a 
German source, Hans Thilo Schmidt, aka "Asché". He contacted the Poles and the British to share this intelligence but the British seemed rather uninterested, contrary to the Poles, who relied on these documents for their first breakthroughs against Enigma. ${ }^{13}$ Regardless, as early as 1938 or 1939 , during a lunch with Menzies, he was offered a golden cigarette case engraved with the royal coat of arms. ${ }^{14}$ This gift proves his significant contribution to British intelligence at such an early date.

Bertrand's biggest contribution to the British codebreaking effort was probably achieved by putting the British cryptanalysts in contact with their Polish counterparts. The Poles had been working on Enigma for some time and they played a central part in the initial breakthrough against the machine. Bertrand played a crucial role in organising two meetings which had a lasting impact on the British cryptanalytic effort against the Enigma ciphering machine. The first took place in Paris in January 1939 and the second and more significant one was organised in Poland, near Pyry, in July 1939. The meeting of January 9-10 took place in the offices of the French SR (Section de Renseignement, Intelligence Division). ${ }^{15}$ The Poles and the British discussed their efforts against Enigma. For the representatives of the three countries, this conference in Paris was a disappointment overall. Denniston, who was at the time head of GC\&CS (Government Code and Cypher School), the British codebreaking centre, recalled in 1948: "At that time we had to regard the meeting as a flop \& that the Poles were no great find." Yet he added: "Since then I have thought that it was our party who were being vetted by the Poles who were at that time reading the traffic \& only wanted to know what progress we had made." ${ }^{16} \mathrm{~A}$ leading British cryptanalyst who attended the meeting, Dillwyn "Dilly" Knox, assessed the Poles' knowledge of Wehrmacht Enigma at the time as "nil." ${ }^{17}$ Denniston himself later described this meeting as a "flop." ${ }^{18}$ There was clear distrust on the part of the three delegations which hid elements from their counterparts. On a number of occasions they chose not to reveal to their partners the full extent of their limited progress into breaking Enigma.

9 However, with the deteriorating European context and the British promise to come to the aid of the Poles should they be attacked, the Poles decided to invite Bertrand and the British to Poland in July 1939. This turned out to be a landmark in the cooperation between the three countries on cryptanalytic matters. Denniston and Knox, who were already present in Paris in January, attended the meeting. So did Bertrand. Despite language difficulties and a few misunderstandings, the Poles finally revealed to the British and the French that they had broken Enigma. They also tried, partly unsuccessfully, to explain how they had managed to do so. ${ }^{19}$ They showed them the machines they used to that end, which they called "bomby" after an ice-cream dessert they had been eating when they invented them. The British thereafter called them "bombes," using the French version of the word. ${ }^{20}$ Knox's initial reaction to these revelations was rather hostile: this could be due to the lengthy and unclear explanation by Ciężki and to language difficulties, or to the frustration of seeing that others had succeeded where he had failed. Later, Knox calmed down and listened carefully to the technical details presented by the staff. In his account of the July meeting Denniston makes the following assessment regarding the Polish revelation about their work on Enigma: "To me Bertrand's attitude remains a mystery. I still believe that he knew all about their work \& feigned the surprise which he manifested at the Polish success." ${ }^{21}$ As late as 1948, when Denniston wrote that account, he doubted Bertrand's sincerity, while in fact the Frenchman discovered the extent of the Polish achievement only one day before the 
British. ${ }^{22}$ In a historic gesture, the Poles promised to give the French and the British two Enigma machines. Once again Bertrand acted as a middleman between the British and the Poles. He was entrusted with the Enigma promised to the British and brought it to Victoria Station in August 1939, where Menzies was expecting him. ${ }^{23}$ The information given by the Poles enabled the British to make crucial progress on Enigma. Bertrand played a central part in all these exchanges, even though his team had not achieved significant progress on Enigma. Denniston himself insisted on the fact that Bertrand was no cipher expert: "Bertrand was no cryptographer \& never pretended that he was. Any technical staff under him must have been very second rate but he had a genius for making use of others" and "Bertrand was, no doubt inter alia, a peddler \& purchaser of foreign government codes \& I think that, as he never had an opportunity in his own organisation of obtaining results from crypt, he had decided to concentrate on careful purchase as the surest method." ${ }^{44}$ Bertrand was also quite scathing about his British counterparts: "The British codebreaking unit is 'stunning' - with regards to its workforce and its means - and yet it is pretty much a complete beginner in this field." 25

In 1939, by putting the Poles and the British in touch with each other, Bertrand significantly contributed to GC\&CS's first successes against Enigma which occurred in January 1940. The beginning of the war in Europe did not bring with it massive changes in the way the French, the British and the Poles cooperated. Despite the invasion of their country, the Polish cryptanalysts made sure no evidence of their successes against Enigma fell into German hands. Following the occupation of Poland, the French and British were in competition to rescue these men and to have them join their intelligence staff. ${ }^{26}$ Evoking the first British successes against Enigma at Bletchley Park, the British cryptanalytic centre, Nigel de Grey, who became its deputy director, underlined the French and Polish contribution to the British work: "The position was to some extent bettered when in January 1940 the solution of Enigma in G.C. \& C.S. began. It was fortunate that the French had been able to rescue some of the Warsaw cryptanalysts who cleared up a mistake in the information previously given and in consequence a trickle of information from Enigma began." ${ }^{27}$ This was however not enough to be able to read Enigma messages continuously. The cryptanalysts had to discover "keys," settings which changed daily, before they could read encrypted communications. The British and the French exchanged these "keys" which enabled them to read the coded messages. ${ }^{28}$ In March, more systematic lines of communication between the two countries were opened, especially through the establishment of a courier service..$^{29}$ This is not to say that there was complete cooperation between the two.

In this regard the work of the historian is made complex by a few factors. Firstly, different versions of Enigma machines existed; they varied depending on the country which used them (mostly Germany and Italy), on the units concerned (air, military, naval, or police forces, intelligence services, etc), and over time. The collaboration between the British and the French was sometimes restricted to only one of these machines. In addition, what is mentioned in the archives and in the communication between the different countries was generally what was being shared, not what was hidden from one's allies. An exchange between the War Office and GC\&CS from November 1939 highlights the stakes, the dilemmas for intelligence officers and war leaders, and some of the solutions found to the eternal question of the extent to which cooperation between the two countries should go. The message deserves to be quoted at length: 
How far is it permissible to give the French information obtained from an intercept?

I believe some of your people have been over to the French and you have had Frenchmen to visit you.

From our point of view, it is desirable that the French should be given any information which vitally concerns them. They would be told it came from a very reliable source, unless, of course, you would not object to their being told it came from an intercepted message. Could you kindly let me know what we can do? Belgium and France. Operation Dynamo, the evacuation of Allied troops from Dunkirk at the end of May and the very beginning of June, made it possible for Allied soldiers, in particular 139,000 French soldiers, to escape the enemy. Yet it created resentment among the French, especially General Weygand, the evacuation of whose forces, he believed, was not given the same priority as that of the British. ${ }^{34}$ In France, an armistice with Germany was signed on June 22. De Gaulle's call to arms on June 18 remained mostly unheard. The French population was very divided on how to react to this defeat. As for the British, they were disappointed by the French who had promised not to accept a separate peace and they were left very isolated in the fight against Germany.

The German threat to France and the armistice caused much disarray among the British. This took a specific form at GC\&CS. The advanced cryptanalytic cooperation with the French meant that if the French or Polish cryptanalysts were captured by the Germans, or if their machines or documents were found, the Third Reich could discover that its codes had been broken. This would virtually put an end to the British ability to read German messages since the ciphering methods would immediately be changed. 
18 At that time, the cryptanalysts working for Bertrand at PC Bruno were under the authority of the Fifth (Intelligence) Bureau of the French general staff. They were based at Château de Vignolles, 20 miles from Paris. There was no knowing where the advance of German troops would stop. Bertrand decided to move his units south. He had destroyed a large quantity of documents so as not to betray their cryptanalytic successes to the Germans. Bertrand drove Captain MacFarlane, a Briton acting as a liaison officer between the two countries, to Cazaux, so that he could leave France by plane. ${ }^{35}$ Bertrand then settled at Bon Entente seminary close to Agen. ${ }^{36}$ On June 23, Denniston sent a message to Bertrand inviting him, his team and the Poles to go to England. Bertrand answered three days later, declining the offer. He declared that the Poles had already left for Algeria. They had done so on June 24, one day after the invitation from Denniston was sent. ${ }^{37}$ Was the invitation received belatedly, due to the chaos of the exodus? Or did Bertrand intentionally ignore this message to keep control over the Polish unit? In his message on June 26, Bertrand also explained that the French officers were not allowed to go to England. Two days letter, Bertrand sent a further message to Denniston announcing: "Had to stop work, but hope to begin again soon. You can rely on me to safeguard security of your work." 38 This message clearly shows Bertrand was acutely aware of the security concerns of the British after the invasion of France. Bertrand had burnt many documents which could reveal and jeopardize the activities of Bletchley Park, and he hid many others, which allowed him to claim in 1972 that no incriminating material was seized by the Germans in $1940 .{ }^{39}$

In July the Fifth Bureau was dissolved by the Vichy regime. ${ }^{40}$ By October 1940, Bertrand's Polish, Spanish (Republican), and French teams had resumed their activities. ${ }^{41}$ Their headquarters was known as PC Cadix and they were based at Château des Fouzes, near Uzès, north of Nîmes, with the support of General Weygand, one of Vichy's highest officials. His unit was known as MA 2, one of the clandestine agencies of the French secret services headed by Colonel Louis Rivet (his position was most complex, some of his agencies had an official status, others were completely clandestine units). A large part of Bertrand's French staff was demobilised after the armistice and chose not to take the risk of continuing to work under his authority. After protracted negotiations, Bertrand managed to convince the Poles ("the $\mathrm{Z}$ team") that their efforts could be more fruitful in France than in England, where their government in exile was based. Bertrand's unit operated on a partly clandestine basis, but he benefited from the support of several Vichy officials who turned a blind eye to his activities. ${ }^{42}$ He adopted the pseudonym "M. Barsac." His position was ambiguous. For instance, he had to swear an oath of loyalty to Marshal Pétain in September $1941 . .^{43}$ There were also portraits of Pétain and Darlan on the walls of PC Cadix, even though he did not expect any visit from Vichy officials or from the police. ${ }^{44} \mathrm{He}$ hoped to be at greater liberty in Vichy France, which would enable him to try to weaken Germany by attacking its codes.

20 An incident in July 1940 could have deterred the French from resuming cooperation with the British once their situation was settled. When the armistice was signed, Germany accepted not to take control of the French fleet, provided it was demobilised and decommissioned. Darlan, the Commander-in-Chief of the French Navy, had promised the British that he would not let the French fleet fall into German hands. On June 24, he gave the order to scuttle the fleet if it was threatened. Yet the British, seeing the risk of such a situation, launched "Operation Catapult" to prevent such a turn of events. At Mers El-Kébir, near Oran, the situation got out of control. The French 
were given an ultimatum: they could join the British fleet, accept to be disarmed, or scuttle their ships. They refused and the British opened fire, leading to the death of 1,300 men. ${ }^{45}$ The French government decided to sever diplomatic relations with the United Kingdom. This tragedy deterred many people in France from cooperating with the British later in the war and in most likelihood greatly shocked Bertrand and his colleagues.

In September 1940, with the support of Free French forces, the British sailed towards Dakar, the capital of French West Africa and a strategically placed port. They hoped Dakar would agree to turn against Vichy. They were wrong. They then attempted to seize the port but failed. ${ }^{46}$ In spite of this and the British blockade of some of Vichy's African colonies, London tried to maintain indirect contact with the French government during the autumn of 1940 for three main reasons. They wanted to make sure the French fleet headed by Darlan would not fall into German hands, which would have constituted a breach of the terms of the armistice. This could have made the British military position even more precarious, at a time when the British feared Germany might invade their territory. Secondly, they feared Vichy might allow the Germans to take control of the French overseas territories, or to attack the colonies which had rallied to de Gaulle. And finally, they hoped to convince Vichy to keep its collaboration with Germany to a minimum. ${ }^{47}$ As R. T. Thomas puts it: "it is difficult to discern a clear pattern in Britain's policy towards Vichy, or even make, in regard to that policy, a single statement which does not require endless qualifications." ${ }^{48}$

In this context, the British cryptanalysts were reluctant to resume their exchanges with the French once Bertrand had established PC Cadix. In September, discussing a meeting with a French emissary in Lisbon to give him a radio transmitter, Dunderdale, who had often served as a liaison between the two countries, declared he intended to give the French "harmless stuff" while "exploiting every opportunity of obtaining information." ${ }^{49} \mathrm{~A}$ letter from Dunderdale highlights the issues at stake: the British wished to continue this cooperation, but they feared it might jeopardize their work. He acknowledged that the French had done their utmost to preserve their secret, and then added:

It is difficult to see how they can handle anything we send them, except as a hobby, they cannot use results which are vital to us. I confess it marvellous that they have maintained touch with each other and safeguarded our work.

They could do us immense harm, if they were not loyal to us, and they have done us no harm..$^{50}$

23 The word 'hobby' used here can seem quite offensive, dismissing the French efforts as meaningless. This document also reveals the distrust of the British who feared they might be betrayed by these unlikely allies in Vichy France. In another letter, written three days later, the options the British had are presented even more clearly. The crucial contribution of the French to British cryptanalysis is, again, underlined:

2. Our liaison with the French from 1938 onwards had considerable effect on the work, but more especially on the E [Enigma] work. It must be recorded that without this liaison with the Poles, arranged by the French, we might not have been able to break in late 1939 and thereafter establish daily contact.

3. The French and the Poles are quite aware of this, and in the last telegram from the French in July they undertook to safeguard us. This they have done in some unexplained manner. ${ }^{51}$

The author adds that the British needed further information on who the French were actually working for: "If they are officially paid by a Government which may join the Nazis at 
any time, it is too risky for us." He suggests they could promise to resume cooperation with the French at a later date should there be a plan for " $a$ French 'come back'." 52 The author belittles the interest of the French for this cryptanalytic work as purely "academic interest," while saying their activities involve "the Defence of Britain." This does not do justice to the complexity of the French situation. In this letter intended for British readers, the author goes even further, claiming that if the lack of British cooperation became too obvious, it could create resentment, with dire consequences: "with the knowledge they possess they can be dangerous to us either as enemies or neutrals." These are very harsh words showing the suspicion of the British. The following month, in December 1940, the British were still asking the French to give details as to the exact recipients of the information they might send them, thus showing their security concerns. $^{54}$

Radio communications between the two finally resumed in March $1941 . .^{55}$ However, the cooperation was very tense. In June 1941, the French reproached the British for not sending them all the 'keys' they needed. They questioned their claim that this was due to cryptanalytic difficulties. They had the feeling the British were still questioning their loyalty or at least the security of their activities. The French were still insisting that they were working in safe conditions and were sheltered from the grasp of the Gestapo. ${ }^{56}$ On June 15, Denniston put forward his plan to give their French counterparts explanations accounting for the supposed inability of the British to break into Enigma. This was a downright lie. He hoped that he could thus avoid irritating the French. ${ }^{57}$ They had insisted they needed to be kept informed of the latest developments to be able to assist the British should the United Kingdom be invaded. Denniston underlined the irony of this claim. ${ }^{58}$ At the same time, in the Middle East, British and Free French troops were trying to seize control of Lebanon and Syria, where the German air force had used Vichy airfields. These events certainly did nothing to improve the strained relations between the cryptanalysts of the two countries. Throughout the following months, Bertrand repeatedly accused the British of not cooperating fully. On December 6, 1941, he asked the British: "Is it really true that you have no results on the E. machine [...] ?"59 In March 1942, he openly questioned the British affirmation that they did not have the key he was asking for and explained this might antagonize some of their allies. ${ }^{60}$ A note from April 1942 for " $C$ ", the head of the Secret Intelligence Service, indicates that the British only gave " $E$ ' [Enigma] Settings of a minor character" to the French. ${ }^{61}$

As we see in these documents, the position of Bertrand's unit was indeed complex. The collaboration with Britain was a key element of his work. But this cooperation with the United Kingdom was sometimes regarded as a problem by his superiors. In September 1940, General Huntziger, the new French War Minister, explicitly forbade any contact between Rivet and the British Secret Intelligence Service. Rivet's account of his briefing and his orders should be quoted at length for what it reveals about Vichy's dilemmas:

1/ General situation: France defeated. War goes on between two enemies. We don't know who will win. England is unlikely to win, compromise possible, Germany the most likely to win. Meanwhile, France must stick loyally to the provisions of the armistice. So no intelligence work on Germany.

2/ No collaboration with Intelligence Service for fear of reprisals against our whole country. [...] Do not give anything to the English.

3/ [...] Don't allow political feelings to influence intelligence work. Only official government matters ${ }^{62}$ 
Rivet added to these notes that Huntziger was maybe not expressing his own feelings and only following orders. A note from October 11 reveals a shift in these formal guidelines. French officers could resume contact with the Intelligence Service, under certain conditions. The objective was to "gather information on England." 63 The position of these agencies was extremely ambiguous. Rivet's relatives declared he had refused to take an oath of loyalty to Pétain, but there is no proof of this. ${ }^{64}$ In October 1941, Bertrand wrote to the British to tell them he had been ordered to cut all ties to the United Kingdom if he did not want to face very harsh sanctions. He put an end to his use of diplomatic bags since he feared this means of communication was no longer secure and the French Ministry of Foreign Affairs may have been reading his messages with disastrous consequences. Bertrand explained that he and his British partners would have to be very cautious in their future exchanges. ${ }^{65} \mathrm{After}$ a report revealed that the British Secret Intelligence Service was using Polish agents in France, Rivet provided Vichy officials with some carefully drafted reports containing half-truths about machine ciphers to show that Bertrand was indeed spying on the British. ${ }^{66}$ Relations between Vichy and the United Kingdom were more than tense, as we can see in a speech Churchill delivered to the Canadian Parliament on December 30, 1941. He used very harsh words to describe Vichy France: "But the men of Bordeaux, the men of Vichy, [...] they lay prostrate at the foot of the conqueror. They fawned upon him." Yet he added:

And everywhere in France, occupied and unoccupied, for their fate is identical, these honest folk, this great people, the French nation, are rising again. Hope is springing up again in the hearts of a warrior race, even though disarmed, [...] We shall never lose confidence that France will play the role of free men again and, by hard paths, will once again attain her place in the great company of freedombringing and victorious nations. ${ }^{67}$

Bertrand was certainly one of them. Events such as the British attack on the French colony of Madagascar, which started in May 1942, show how complex this alliance between Bertrand and his British counterparts was. ${ }^{68}$ In July 1942, Prime Minister Pierre Laval, head of the Vichy government, ordered Rivet to put an end to his antiGerman activities. In September 1942 Rivet was replaced, and Vichy's intelligence agencies were completely reorganised to give Laval a firmer grip on them. ${ }^{69}$ Yet he was in the dark about Bertrand's real activities and Bertrand was able to continue his work despite the renaming of his unit. ${ }^{70}$

\section{Operation Torch and the end of an unlikely alliance}

All this was abruptly put to an end by the invasion of Vichy France by German troops in the wake of Operation Torch, the Allied landings in North Africa in November 1942. The staunch resistance of Vichy troops in North Africa came as a surprise to the Free French and the British. Bertrand had been making contingency plans and had hidden Enigma to ensure it would not be seized by the Germans, who might then have discovered the extent of the Allied cryptanalytic successes against this machine. ${ }^{71}$ In his book, he declares that he had also transferred to London many of the archives which the Poles had brought to France when they fled their country in 1939..$^{72}$ By November 9 , Cadix was completely evacuated and all the documents were hidden (some had been buried inside the walls of the castle), destroyed or moved. ${ }^{73}$ Three days later, the Germans occupied the site. ${ }^{74}$ Unfortunately, the evacuation of the staff was not as successful as it had been in June 1940. Plans had been made with the British to evacuate 
the personnel but they all failed..$^{75}$ The Polish cryptanalysts felt Bertrand left them to their fate, or even betrayed them, which is extremely unlikely. ${ }^{76}$ Some of them were captured by the Germans a few months later in February and March 1943. The Germans were looking for Antoni Palluth, one of the greatest Polish cryptanalysts, but they never realised that they were already holding him prisoner. One of his colleagues, Lieutenant Colonel Gwido Langer, was also arrested by the Germans but he managed to reveal nothing about the Allied successes and made sure he did not contradict the statements of another captive colleague, CiĘżki. In all likelihood, they convinced their German interrogators that the changes brought to Enigma before the war had prevented the Allies from reading the messages produced on it. ${ }^{77}$ Another accident could have put an end to the Allied cryptanalytic successes. In March 1943, a man presenting himself as "Rodolphe Lemoine" revealed to the Germans that a man called Hans Thilo Schmidt had given the cryptanalysts precious information on Enigma before the war. Schmidt was arrested and eventually committed suicide. Nonetheless, this confession by Lemoine did not worry the Germans excessively. ${ }^{78}$

The evacuation of Cadix put an end to the French cryptanalytic activities until France was liberated in $1944 .{ }^{79}$ Bertrand soon resumed his intelligence activities. In June 1943 he had become the effective head of the clandestine "Kléber" intelligence network, and its official leader in December. ${ }^{80} \mathrm{He}$ was arrested in January 1944 with several incriminating documents proving he was spying on the Germans and sending this intelligence to the British. He should have been executed, but the German Abwehr suggested that instead he should carry on his radio exchanges with the British under German control, thus becoming a double agent. He claims to have accepted because he was certain that he could warn his British counterparts he had been caught. ${ }^{81} \mathrm{He}$ escaped 6 days after his arrest. ${ }^{82}$ He later went to London where he joined the BCRA, the Free French intelligence agency, and then became the head of the Second Bureau of the French Forces of the Interior. At the end of 1944, he took charge of the Technical Research Service of the DGER. ${ }^{83}$

31 Bertrand resumed contact with the British in November 1944. The British messages from this period refer to him using his alias "Gaudefroy". The British thanked him for preserving their secret after November 1942. They explained they wanted to work with him again, but wanted to take their time, until the political and military situation was clearer and his team better established. ${ }^{84} \mathrm{~A}$ British note from that month explains they now felt reassured because very few people received intelligence from Bertrand. ${ }^{85}$

\section{Conclusion}

Several lessons can be drawn from the complex yet crucial cooperation between Gustave Bertrand and the British. His most significant contributions probably came before the war when he obtained the Asché documents and a few years later when he put the Polish and the British cryptanalysts in touch with one another. Yet substantial exchanges also took place under the Vichy regime, until the turning point of November 1942. These French efforts were also crucial since they showed that among the French who chose to remain in France after the Armistice were key players in the fight against the Axis, thus giving them some legitimacy at the end of the war. However, very little information was shared when contact was resumed at the end of 1944. Bertrand's dilemmas show how divided Vichy was. Bertrand's intrigues also show that, contrary to 
what some claim, there was a margin of freedom and some space for resistance inside the defeated country, though the evolution of the regime towards fuller collaboration with Germany made his position increasingly difficult. Despite the common description of French intelligence as inadequate, which the debacle of 1940 seems to confirm, Bertrand and his team played a crucial role in the development of Allied sigint, which, it is now estimated, probably shortened the war by two or three years. ${ }^{86}$ This cooperation also paved the way for the massive expansion of the British codebreaking centre which became a world leader in the field.

\section{BIBLIOGRAPHY}

\section{Sources}

\section{British Archives, Kew, United Kingdom}

HW 14 Government Code and Cypher School: Directorate: Second World War Policy Papers

HW 25 Government Code and Cypher School: Cryptographic Studies

HW 43 Government Code and Cypher School: Histories of British Sigint

HW 50 Government Code and Cypher School and Government Communications Headquarters: Records relating to the writing of the history of British signals intelligence in World War II

HW 65 Government Code and Cypher School: Anglo-French Liaison Records

\section{Service historique de la défense (French Military Archives), Vincennes, France}

Gustave Bertrand's military file: 16P55057.

Bertrand files (declassified in 2015): DE 2016 ZB 25.

\section{Bibliography}

Andrew, Christopher and Noakes, Jeremy, Intelligence and International Relations, 1900-1945 (Exeter, University of Exeter, 1987).

Andrew, Christopher, "La place de la Première Guerre mondiale dans l'histoire du renseignement" at a conference on "Espionnage et renseignement dans la Première Guerre mondiale”, November 26, 2014, École militaire, Paris.

Batey, Mavis, Dilly. The Man Who Broke Enigmas (London, Biteback, 2010).

Bertrand, Gustave, Enigma ou la plus grande énigme de la guerre 1939-1945 (Paris, Plon, 1972). 
Beltjens, François, Mers el Kébir 3 juillet 1940 : Exécution, ou bataille perdue (Paris, Godefroy de Bouillon, 2000).

Brown, David, The Road to Oran: Anglo-French Naval Relations, September 1939-July 1940 (London, Cass, 2004).

Churchill, Winston, Speech to the Canadian Parliament, December 30, 1941, https:// www.nationalchurchillmuseum.org/some-chicken-some-neck.html Consulted 4 October 2019 Churchill, Winston, Speech to the House of Commons, June 12, 1945, https://api.parliament.uk/ historic-hansard/commons/1945/jun/12/united-kingdom-and-vichy-governments Consulted 4 October 2019.

Coutau-Bégarie, Hervé and Huan, Claude, Mers el-Kébir 1940 : la rupture franco-britannique (Paris, Economica, 1994).

Erskine, Ralph, “The Poles Reveal their Secrets: Alastair Denniston's Account of the July 1939 Meeting at Pyry", Cryptologia XXX:4 (2006), pp. 294-305.

Jeffery, Keith, MI6: The History of the Secret Intelligence Service, 1909-1949 (London, Bloomsbury, 2011).

Kaspi, André, Piétri, Nicole, and Schor, Ralph, Chronologie commentée de la Seconde Guerre mondiale (Paris, Perrin, 2010).

O'Halpin, Eunan (ed.), MI5 and Ireland, 1939-1945: The Official History (Dublin, Irish Academic Press, 2003).

O'Halpin, Eunan, “Small States and Big Secrets: Understanding Sigint Cooperation between Unequal Powers during the Second World War", Intelligence and National Security XVII: 3 (2002), pp. 1-16.

Rivet, Louis, Carnets du chef des services secrets, 1936-1944 (Paris, Nouveau monde éd, 2010). Sebag-Montefiore, Hugh, Enigma: The Battle for the Code (London, Weidenfeld \& Nicolson, 2000). Smith, Bradley F., Sharing Secrets with Stalin: How the Allies Traded Intelligence, 1941-1945 (Lawrence, University Press of Kansas, 1996).

Smith, Michael, interviewed by Prof. Christopher Andrew in an episode of the BBC 4 "What If" series, April 24, 2003, http://www.bbc.co.uk/radio4/history/whatif/what_if.shtml Consulted April 3, 2009.

Thomas, Martin, "Imperial Backwater or Strategic Outpost? The British Takeover of Vichy Madagascar, 1942”, The Historical Journal XXXIX:4 (1996), pp. 1049-1074.

Thomas, Martin, "Signals Intelligence and Vichy France, 1940-44: Intelligence in Defeat", Intelligence and National Security XIV: 1 (1999), pp. 176-200.

Thomas, R.T., Britain and Vichy: The Dilemma of Anglo-French Relations, 1940-1942 (New York, St Martin's Press, 1979).

Tsarev, Oleg and West, Nigel, The Crown Jewels: The British Secrets at the Heart of the KGB Archives (London, HarperCollins, 1999).

Turing, Dermot, X, Y \& Z: The Real History of How Enigma Was Broken (Stroud, The History Press, 2018). 


\section{NOTES}

1. Christopher Andrew and Jeremy Noakes, Intelligence and International Relations, 1900-1945 (Exeter, University of Exeter, 1987).

2. To quote but a few researchers, we should mention the works of Richard J. Aldrich, Robert L. Benson, Stephen Budiansky, Lee A. Galdwin, Michael Smith or Ralph Erskine. Ralph Erskine also took an interest in the crucial meeting of July 1939 between the Poles, the French and the British in his article: "The Poles Reveal Their Secrets", Cryptologia XXX: 4, 2006, pp. 294-305.

3. Eunan O'Halpin, (ed.), MI5 and Ireland, 1939-1945: The Official History (Dublin, Irish Academic Press, 2003) and "Small States and Big Secrets: Understanding Sigint Cooperation between Unequal Powers during the Second World War", Intelligence and National Security XVII: 3, 2002.

4. Bradley F. Smith, Sharing Secrets with Stalin: How the Allies Traded Intelligence, 1941-1945 (Lawrence, University Press of Kansas, 1996).

5. Hugh Sebag-Montefiore, Enigma: The Battle for the Code (London, Weidenfeld \& Nicolson, 2000).

6. Dermot Turing, $X Y \&$ Z . The Real Story of How Enigma Was Broken, (Stroud, The History Press, 2019). " $X$ " was Paris, " $Y$ " London and " $Z$ " Warsaw in the exchanges between the cryptanalysts of the three countries. Message 211 from British liaison officer Wilfred Dunderdale, undated (The National Archives, hereafter TNA, Kew, HW 25/12).

7. Two authors, Sébastien Albertelli and Young de la Marck have extensively studied the cooperation of the Free French with British intelligence. There was no connection between Bertrand and the Free French intelligence service until his agency stopped working in November 1942.

8. Some documents, both in France and in the United Kingdom, remain classified, while many documents were destroyed during and after the war.

9. Lecture by Christopher Andrew "La place de la Première Guerre mondiale dans l'histoire du renseignement" at a conference on "Espionnage et renseignement dans la Première Guerre mondiale", November 26, 2014, École militaire, Paris.

10. Louis Rivet, Carnets du chef des services secrets, 1936-1944 (Paris, Nouveau monde éd, 2010), p. 167.

11. Introduction by Olivier Forcade, Carnets du chef des services secrets, 1936-1944 (Paris, Nouveau monde éd, 2010), p. 39.

12. Nigel West and Oleg Tsarev, The Crown Jewels: The British Secrets at the Heart of the KGB Archives (London, HarperCollins, 1999), p. 308.

13. Louis Rivet, Carnets du chef des services secrets, 1936-1944 (Paris, Nouveau monde éd, 2010), p. 794. A short biography written by Oliver Forcade and Sébastien Laurent can be found at the end of the book.

14. Alastair G. Denniston, "How News was Brought from Warsaw at the end of July 1939", 1948 (TNA, HW 25/12).

15. Gustave Bertrand, Enigma ou la plus grande énigme de la guerre 1939-1945 (Paris, Plon, 1972), pp. 57-58.

16. Alastair G. Denniston, "How News was Brought from Warsaw at the end of July 1939", 1948 (TNA, HW 25/12).

17. Alfred Dillwyn “Dilly” Knox, Memorandum, January 13, 1939 (TNA, HW 25/12).

18. Alastair G. Denniston, 1948. "How News was Brought from Warsaw at the end of July 1939", 1948 (TNA, HW 25/12).

19. Ibid.

20. Mavis Batey, Dilly. The Man Who Broke Enigmas (London, Biteback, 2010), p. 95.

21. Ibid.

22. Gustave Bertrand, Enigma ou la plus grande énigme de la guerre 1939-1945 (Paris, Plon, 1972), p. 59. 
23. Ibid., pp. 60-61.

24. Alastair G. Denniston, 1948, 'How News was Brought from Warsaw at the end of July 1939', 1948 (TNA, HW 25/12).

25. "Le Service de Décryptement brit est 'écrasant' - quant à ses effectifs et à ses moyens - ce qui ne l'empêche pas d'être encore, pratiquement, à zéro en la matière", Gustave Bertrand, "Contribution à l'étude de la machine à chiffrer 'Enigma' (type Wehrmacht) par le S.R. de l'E.M.A.” (1931-1942), tome 2, p. 151 (Service Historique de la Défense, Vincennes, DE 2016 ZB 25, Box 1).

26. Gustave Bertrand, Enigma ou la plus grande énigme de la guerre 1939-1945 (Paris, Plon, 1972), p. 69.

27. Nigel de Grey, Allied Sigint Policy and Organisation (unpublished), chapter X, section 1 "French Liaison", p. 5 (TNA, HW 43/78).

28. Ibid.

29. Martin Thomas, "Signals Intelligence and Vichy France, 1940-44: Intelligence in Defeat", Intelligence and National Security XIV: 1, 1999, p. 179.

30. Letter from J. Spencer to A. G. Denniston, November 18, 1939 and letter from A.G. Denniston to J. Spencer, November 24, 1939 (TNA, HW 14/2).

31. Nigel de Grey, Allied Sigint Policy and Organisation (unpublished), chapter X, section 1 "French Liaison", p. 4 (TNA, HW 43/78) and Note entitled "French liaison. Field Level" (undated) (TNA, HW 50/10).

32. Nigel de Grey, Allied Sigint Policy and Organisation (unpublished), chapter X, section 1 "French Liaison", p. 5 (TNA, HW 43/78).

33. For instance, letter from Gustave Bertrand to A.G. Denniston, February 25, 1940 (TNA, HW 65/4).

34. André Kaspi, Piétri, N. and R. Schor, Chronologie commentée de la Seconde Guerre mondiale (Paris, Perrin, 2010), pp. 108-109.

35. Introduction by Olivier Forcade to a section in Louis Rivet, Carnets du chef des services secrets, 1936-1944 (Paris, Nouveau monde éd, 2010), p. 300. Gustave Bertrand, Enigma ou la plus grande énigme de la guerre 1939-1945 (Paris, Plon, 1972), pp. 101-102.

36. Louis Rivet, Carnets du chef des services secrets, 1936-1944 (Paris, Nouveau monde éd, 2010), p. 402.

37. Gustave Bertrand, Enigma ou la plus grande énigme de la guerre 1939-1945 (Paris, Plon, 1972), pp. 101-102.

38. Note "French liaison. Poles \& E keys for Bertie" (undated) (TNA, HW 50/10).

39. Gustave Bertrand, Enigma ou la plus grande énigme de la guerre 1939-1945 (Paris, Plon, 1972), pp. 99-103.

40. Ibid., pp. 101-102.

41. Ibid., p. 107.

42. Martin Thomas, "Signals Intelligence and Vichy France, 1940-44: Intelligence in Defeat", Intelligence and National Security XIV: 1, 1999, p. 179.

43. Gustave Bertrand, Enigma ou la plus grande énigme de la guerre 1939-1945 (Paris, Plon, 1972), pp. 101-113.

44. Dermot Turing, $X Y \&$ Z. The Real Story of How Enigma Was Broken (Stroud, The History Press, 2019), p. 186.

45. Many books recount in detail the events at Mers el-Kébir. We can mention for instance: François Beltjens, Mers el Kébir 3juillet 1940: Exécution, ou bataille perdue (Paris, Godefroy de Bouillon, 2000); David Brown, The Road to Oran: Anglo-French Naval Relations, September 1939-July 1940, (London, Cass, 2004); Hervé Coutau-Bégarie and Claude Huan, Mers el-Kébir 1940 : la rupture franco-britannique (Paris, Economica, 1994).

46. André Kaspi, Piétri, N. and R. Schor, Chronologie commentée de la Seconde Guerre mondiale (Paris, Perrin, 2010), pp. 185-186. 
47. Winston Churchill, speech to the House of Commons, June 12, 1945, https:// api.parliament.uk/historic-hansard/commons/1945/jun/12/united-kingdom-and-vichygovernments Consulted 4 October 2019.

48. R. T. Thomas, Britain and Vichy: The Dilemma of Anglo-French Relations, 1940-1942 (New York, St Martin's Press, 1979), pp. 178-179.

49. Keith Jeffery, MI6: The History of the Secret Intelligence Service, 1909-1949 (London, Bloomsbury, 2011), p. 393.

50. Letter to Dunderdale, most probably from Denniston, November 12, 1940 (TNA, HW 14/8).

51. Letter headed 'French liaison', November 15, 1940, no indication of the author or recipient (TNA, HW 14/8).

52. Ibid.

53. Ibid.

54. Letter for the Director, "Resumption of liaison with the French", December 24, 1940, (TNA, HW 14/9).

55. Gustave Bertrand, Enigma ou la plus grande énigme de la guerre 1939-1945 (Paris, Plon, 1972), pp. 129-130.

56. Telegram 22 from Bertrand for the British, June 12, 1941 (TNA, HW 14/16).

57. Letter from Denniston for the Director, June 15, 1941 (TNA, HW 14/16).

58. Telegram 22 from Bertrand for the British, June 12, 1941 and Letter from Denniston for the Director, June 15, 1941 (TNA, HW 14/16).

59. "Est-ce que vraiment vous n'avez aucun resultat [sic] sur machine E [...] ?" (All translations author's own). Message by Gustave Bertrand to the British, December 6, 1941 (TNA, HW 14/24).

60. Telegram 98 from Bertrand for the British, March 16, 1942 (TNA, HW 65/7).

61. Note for CSS (The head of the Secret Intelligence Service), April 9, 1942 (TNA, HW 65/7).

62. "1. Situation générale : France vaincue. Guerre poursuivie entre deux adversaires dont on ne sait qui sera vainqueur. Angleterre a peu de chances, compromis possible, Allemagne a le plus de chances. En attendant, France doit exécuter loyalement clauses de l'armistice. Donc pas de travaille SR sur Allemagne.

2. Pas de collaboration avec Intelligence Service par craintes de représailles sur pays tout entier. [...] Ne rien fournir aux Anglais.

3. [....] Ne pas se laisser influencer dans travail SR par sentiments politiques. Seul gouvernement régulier compte."

The editor of Rivet's diaries in charge of this section of the book, Sébastien Laurent, explains that these guidelines were not adhered to before or after this meeting. Bertrand's work is a blatant example of this. Louis Rivet, Carnets du chef des services secrets, 1936-1944 (Paris, Nouveau monde éd, 2010), p. 438.

63. "recueillir renseignements sur Angleterre." Ibid, p. 440.

64. Introduction by Sébastien Laurent to a chapter in Louis Rivet, Carnets du chef des services secrets, 1936-1944 (Paris, Nouveau monde éd, 2010), p. 442.

65. Telegram 5 by Bertrand, October 24, 1941 (TNA, HW 65/7).

66. Dermot Turing, $X Y \&$ Z. The Real Story of How Enigma Was Broken (Stroud, The History Press, 2019), p. 196.

67. Winston Churchill, speech to the Canadian Parliament, December 30, 1941, https:// www.nationalchurchillmuseum.org/some-chicken-some-neck.html Consulted October 42019.

68. Martin Thomas, "Imperial Backwater or Strategic Outpost? The British Takeover of Vichy Madagascar, 1942," The Historical Journal XXXIX:4, 1996), p. 1049.

69. Dermot Turing, $X Y \& Z$. The Real Story of How Enigma Was Broken (Stroud, The History Press, 2019), p. 206.

70. Gustave Bertrand, "Étude et résultats de la recherche du renseignement par les moyens techniques" (1931-1942), tome 1, p. 41 (Service Historique de la Défense, Vincennes, DE 2016 ZB 25, Box 3). 
71. Telegram by Bertrand, October 29, 1942 (TNA, HW 65/7).

72. Gustave Bertrand, Enigma ou la plus grande énigme de la guerre 1939-1945 (Paris, Plon, 1972), pp. 99-101, and pp. 135-141.

73. Footnote by Sébastien Laurent, in Louis Rivet, Carnets du chef des services secrets, 1936-1944 (Paris, Nouveau monde éd, 2010), p. 540.

74. Gustave Bertrand, Enigma ou la plus grande énigme de la guerre 1939-1945 (Paris, Plon, 1972), pp. 139-140.

75. Ibid., pp. 134-141.

76. Dermot Turing, X Y \& Z. The Real Story of How Enigma Was Broken (Stroud, The History Press, 2019), pp. 225-271.

77. Hugh Sebag-Montefiore, Enigma: The Battle for the Code, (London, Weidenfeld \& Nicolson, 2000), pp. 243-274.

78. Ibid., pp. 244-248 and p. 302.

79. Martin Thomas, "Signals Intelligence and Vichy France, 1940-44: Intelligence in Defeat," Intelligence and National Security XIV: 1, 1999, p. 194.

80. Gustave Bertrand's military file (Service Historique de la Défense, Vincennes, 16P55057).

81. Gustave Bertrand, Enigma ou la plus grande énigme de la guerre 1939-1945 (Paris, Plon, 1972), pp. 151-187.

82. Louis Rivet, Carnets du chef des services secrets, 1936-1944 (Paris, Nouveau monde éd, 2010), p. 795.

83. Gustave Bertrand's military file (Service Historique de la Défense, Vincennes, 16P55057).

84. Letter from E.G. Hastings for CSS, November 19, 1944 (TNA, HW 65/7).

85. Ibid.

86. Michael Smith is the defence correspondent for the Daily Telegraph, and the author of Station $X$ as well as the co-editor of Action This Day, on Bletchley Park, which he compiled in collaboration with Ralph Erskine. Interviewed by Prof. Christopher Andrew in an episode of the BBC 4 "What If" series, April 24, 2003, http://www.bbc.co.uk/radio4/history/whatif/what_if.shtml Consulted April 3, 2009.

\section{ABSTRACTS}

This paper investigates the little-known yet crucial part that cooperation with French cryptanalysts played in the remarkable British success in cracking Enigma codes during World War Two. On the French side, the central figure of this alliance was the head of the French army codebreaking unit, Gustave Bertrand. Shortly before the war, he had put British and Polish cryptanalysts in contact with each other, and this became instrumental in allowing the British to decode Enigma messages. After the fall of France in 1940, Bertrand chose to remain in France and, with the support of some leading Vichy officials, kept on working on German codes and cooperated with the British, on a clandestine basis. This entailed huge risks for the two partners. The Allied landing in North Africa all but put an end to this alliance, although a few exchanges did take place after that date. This cooperation paved the way for the massive expansion of the British codebreaking centre, which became a world leader in the field.

Cet article est consacré à l'étude du rôle méconnu mais crucial qu'a joué la coopération des cryptanalystes français avec leurs homologues britanniques pendant la Seconde Guerre 
mondiale : elle a contribué au formidable succès des Britanniques contre les codes produits sur Enigma pendant la Seconde Guerre mondiale. Gustave Bertrand, à la tête de l'agence de cryptanalyse de l'armée française, était le personnage central de cette association du côté français. Peu avant la guerre, il mit en contact des cryptanalystes britanniques et polonais, ce qui contribua grandement à permettre aux Britanniques de décoder les messages Enigma. Après la chute de la France en 1940, Bertrand choisit de rester en France, et avec le soutien de quelques hauts fonctionnaires de Vichy, de poursuivre ses travaux sur les codes allemands en coopérant avec les Britanniques, de façon clandestine. Ceci comportait d'immenses risques pour les deux camps. Le débarquement allié en Afrique du Nord mit un terme presque complet à cette alliance, même si quelques échanges eurent lieu après cette date. Cette coopération ouvrit la voie à l'expansion massive de l'agence de cryptanalyse britannique qui devint un centre de référence dans ce domaine.

\section{INDEX}

Mots-clés: renseignement, Enigma, Seconde Guerre mondiale, Vichy, Royaume-Uni, coopération

Keywords: intelligence, Enigma, World War Two, Vichy, United Kingdom, cooperation

\section{AUTHOR}

\section{MONA PARRA}

ILCEA4, Grenoble Alpes University

Mona Parra is an alumna of ENS Cachan. She teaches at the Grenoble Alpes University where she is a member of the ILCEA4 research team. Her $2015 \mathrm{PhD}$ dissertation was entitled: "The protection of British, American and German intelligence during the Second World War". Her research focuses on the British secret services during this conflict and on their cooperation with Allied intelligence agencies. 